\title{
Extracorporeal membrane oxygenation in non-intubated immunocompromised patients
}

\author{
Klaus Stahl ${ }^{{ }^{*}+} \mathbb{0}$, Heiko Schenk ${ }^{2 \dagger}$, Christian Kühn ${ }^{3}$, OlafWiesner ${ }^{4}$, Marius M. Hoeper ${ }^{4}$ and Sascha David ${ }^{2,5}$
}

Veno-venous (VV) extracorporeal membrane oxygenation (ECMO) has become an integral part in the rescue therapy of severe acute respiratory distress syndrome (ARDS) and may be lifesaving in patients with refractory hypoxemia [1]. Ventilator-induced lung injury, ventilatoracquired pneumonia and ventilator-induced diaphragm dysfunction are severe side effects of invasive ventilation and may contribute to the complex pathophysiology of multi-organ failure and death in ARDS [2]. The use of ECMO in patients who are awake and spontaneously breathing (termed awake ECMO) might avoid side effects and complications associated with sedation, intubation and invasive mechanical ventilation [3]. Our group reported the first successful use of awake ECMO in six ARDS patients several years ago [4]. We then concluded that the concept of an awake ECMO strategy as a potential alternative to intubation deserves further evaluation especially in patients with higher mortality following traditional invasive ventilation and ECMO support.

In immunocompromised patients with ARDS who require ECMO support, the 6-month mortality exceeds $70 \%$ with a reported in-hospital mortality of $81 \%$ in patients following hematopoietic stem cell transplantation (HSCT) [5]. In immunocompromised patients with Pneumocystis jirovecii-associated pneumonia and severe

*Correspondence: stahl.klaus@mh-hannover.de

${ }^{\dagger}$ Klaus Stahl and Heiko Schenk have contributed equally to the manuscript and are both considered first authors

1 Department of Gastroenterology, Hepatology and Endocrinology, Hannover Medical School, Hannover, Germany

Full list of author information is available at the end of the article
ARDS we demonstrated earlier that a primarily awake ECMO strategy seems to be a promising strategy [6].

We therefore hypothesized that awake ECMO support to avoid invasive ventilation in selected immunocompromised patients might yield improved outcomes. Here, we present a comprehensive summary of 18 immunocompromised patients who received awake ECMO support for management of ARDS at our institution between 09/2012 and 09/2020.

The patient characteristics are shown in Table 1. At inclusion, the majority of patients had isolated lung failure indicated by rather low rates of low-dose vasopressor support (28\%) and renal replacement therapy (6\%) as well as physiological serum lactate concentrations. Median (Interquartile Range (IQR)) oxygenation indices at ECMO initiation were $72(65-82) \mathrm{mmHg}$ with normal values for $\mathrm{pH}$ and $\mathrm{pCO}_{2}$ despite maximal respiratory support by noninvasive ventilation (NIV). ECMO was initiated after a median of $1(1-3)$ days following initial ICU admission and was carried out for 11 (9-18) days.

Eleven patients $(61 \%)$ required secondary intubation after a median of 4 (2-6) days. The most common cause for secondary intubation was agitation $(6 / 11,55 \%)$ stressing the critical role for delirium preventive strategies in these patients. The majority $(4 / 6)$ of patients with agitation as primary cause for failing awake ECMO support developed agitation without any prior respiratory or circulatory deterioration. The choice of anxiolytic medication showed a trend toward a more frequent use of benzodiazepines in patients with agitation compared to all other patients (6/6 vs. 4/12), while low-dose morphine was used less frequently (2/6 vs. $7 / 12)$.

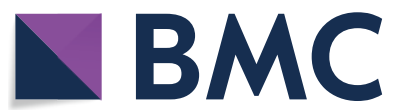

(c) The Author(s) 2021. Open Access This article is licensed under a Creative Commons Attribution 4.0 International License, which permits use, sharing, adaptation, distribution and reproduction in any medium or format, as long as you give appropriate credit to the original author(s) and the source, provide a link to the Creative Commons licence, and indicate if changes were made. The images or other third party material in this article are included in the article's Creative Commons licence, unless indicated otherwise in a credit line to the material. If material is not included in the article's Creative Commons licence and your intended use is not permitted by statutory regulation or exceeds the permitted use, you will need to obtain permission directly from the copyright holder. To view a copy of this licence, visit http://creativecommons.org/licenses/by/4.0/. The Creative Commons Public Domain Dedication waiver (http://creativecommons.org/publicdomain/zero/1.0/) applies to the data made available in this article, unless otherwise stated in a credit line to the data. 
Table 1 Demographic and clinical characteristics at initiation of awake ECMO support

\begin{tabular}{|c|c|}
\hline Characteristic at inclusion & Median (IQR)/no (\%) \\
\hline Number of patients & 18 \\
\hline Age-years & $54(36-60)$ \\
\hline \multicolumn{2}{|l|}{ Sex-no (\%) } \\
\hline Male & $11(61.1)$ \\
\hline Female & $7(38.9)$ \\
\hline $\mathrm{BMl}-\mathrm{kg} / \mathrm{m}^{2}$ & $24.5(21.3-27.1)$ \\
\hline Adipositas (BMl > 30 kg/m²)—no (\%) & $2(11.1)$ \\
\hline \multicolumn{2}{|l|}{ Cause of immunosupression-no (\%) } \\
\hline Solid organ transplant & $7(38.9)$ \\
\hline $\mathrm{HSCT}$ & $6(33.3)$ \\
\hline AIDS & $2(11.1)$ \\
\hline Rheumatological disease & $3(16.7)$ \\
\hline \multicolumn{2}{|l|}{ Pathogen-no (\%) } \\
\hline Gram + & $2(11.1)$ \\
\hline Gram- & $3(16.7)$ \\
\hline CMV & $1(5.6)$ \\
\hline Fungal & $2(11.1)$ \\
\hline PCP & $8(44.4)$ \\
\hline Non-identified & $5(27.8)$ \\
\hline \multicolumn{2}{|l|}{ Comorbidities-no (\%) } \\
\hline COPD & $3(16.7)$ \\
\hline Cystic fibrosis & $1(5.6)$ \\
\hline Pulmonary fibrosis & $6(33.3)$ \\
\hline Pulmonary hypertension & $1(5.6)$ \\
\hline Arterial hypertension & $5(27.8)$ \\
\hline Congestive heart failure & $1(5.6)$ \\
\hline Diabetes mellitus & $3(16.7)$ \\
\hline Chronic kidney disease & $5(27.8)$ \\
\hline \multicolumn{2}{|l|}{ Ventilation support—no (\%) } \\
\hline HFNC & $1(5.6)$ \\
\hline NIV & $17(94.4)$ \\
\hline \multicolumn{2}{|l|}{ Respiratory parameters } \\
\hline $\mathrm{FiO}_{2}$ & $1(1-1)$ \\
\hline $\mathrm{PEEP}-\mathrm{CmH}_{2} \mathrm{O}$ & $7(5-8)$ \\
\hline Breaths per minute & $32(29-38)$ \\
\hline Tidal volume-ml & $593(476-786)$ \\
\hline Minute ventilation-1/min & $21.3(13.8-24.4)$ \\
\hline Peak- $\mathrm{CmH}_{2} \mathrm{O}$ & $17(14-19)$ \\
\hline $\mathrm{P}_{\mathrm{a}} \mathrm{O}_{2}-\mathrm{mmHg}$ & $65(58-82)$ \\
\hline $\mathrm{PaO}_{2} / \mathrm{FiO}_{2}-\mathrm{mmHg}$ & $72(65-82)$ \\
\hline $\mathrm{P}_{\mathrm{a}} \mathrm{CO}_{2}-\mathrm{mmHg}$ & $40(35-59)$ \\
\hline $\mathrm{pH}$ & $7.36(7.3-7.44)$ \\
\hline Lactate-mmol// & $1.5(1.2-1.9)$ \\
\hline Vasopressor-no (\%) & $5(27.8)$ \\
\hline Norepinephrine dose- $\mu \mathrm{g} / \mathrm{kg} / \mathrm{min}$ & $0(0-0.068)$ \\
\hline Inotropic-no (\%) & $0(0)$ \\
\hline Renal replacement therapy—no (\%) & $1(5.6)$ \\
\hline SOFA-score (points) & $7(4-8)$ \\
\hline Organ dysfunction-no (\%) & \\
\hline
\end{tabular}

Table 1 (continued)

\begin{tabular}{|c|c|}
\hline Characteristic at inclusion & Median (IQR)/no (\%) \\
\hline Respiratory $\left(\mathrm{P}_{\mathrm{a}} \mathrm{O}_{2} / \mathrm{FiO}_{2}<300\right)$ & $18(100)$ \\
\hline Coagulation (thrombocytes < 100) & $5(27.8)$ \\
\hline Liver (bilirubin > $33 \mu \mathrm{mol} / \mathrm{l})$ & $2(11.1)$ \\
\hline Cardiovascular (dobutamine or noradrenaline) & $5(27.8)$ \\
\hline Neurological (GCS < 13) & $0(0)$ \\
\hline Renal (creatinine $>170 \mu \mathrm{mol} / \mathrm{l})$ & $3(16.7)$ \\
\hline \multicolumn{2}{|l|}{ Multi-organ dysfunction—no (\%) } \\
\hline Two & $11(61.1)$ \\
\hline Three & $1(5.6)$ \\
\hline Four & $1(5.6)$ \\
\hline Five & $0(0)$ \\
\hline Six & $0(0)$ \\
\hline $\mathrm{CRP}-\mathrm{mg} / \mathrm{l}$ & $173(78-226)$ \\
\hline $\mathrm{PCT}-\mu \mathrm{g} / \mathrm{l}$ & $0.8(0.3-1.5)$ \\
\hline Creatinine $-\mu \mathrm{mol} / \mathrm{l}$ & $69(53-107)$ \\
\hline $24 \mathrm{~h}$ diuresis—ml & $1230(360-2165)$ \\
\hline \multicolumn{2}{|l|}{ ECMO settings (directly after cannulation) } \\
\hline Veno-venous & $18(100)$ \\
\hline \multicolumn{2}{|l|}{ Cannulation (inflow-outflow) } \\
\hline Femoral-jugular & $16(88.8)$ \\
\hline Femoral-femoral & $1(5.6)$ \\
\hline Femoral-subclavia & $1(5.6)$ \\
\hline Pump speed_rpm & $3410(3030-3671)$ \\
\hline Blood flow $-1 / \mathrm{min}$ & $3.6(3.3-4)$ \\
\hline $\mathrm{FiO}_{2}$ & $100(100-100)$ \\
\hline Sweep gas flow-1/min & $3.5(2-4.1)$ \\
\hline
\end{tabular}

Description of the patient cohort $(n=18)$ that received awake ECMO support. All immunocompromised patients with severe ARDS were non-systematically screened by two ECMO experienced ICU attending intensivists for the possibility of an awake ECMO strategy following inclusion and exclusion criteria that have been previously defined by our group as part of the study describing first use of awake ECMO in ARDS patients (4) (NCT01669863). In general, the exclusion criteria stressed the absence of septic or cardiogenic shock and multi-organ failure

Given are demographic and clinical characteristics at the time of ECMO initiation. Values are presented as median (25-75\% interquartile range) or if categorical as numbers and percentage

BMI, Body Mass Index; HSCT, Hematopoietic Stem Cell Transplantation; AIDS, Acquired Immuno Deficiency Syndrome; CMV, Cytomegalovirus; PcP, Pneumocystis carinii Pneumonia; COPD, Chronic Obstructive Pulmonary Disease; HFNC, High Flow Nasula Cannula; NIV, Non Invasive Ventilation; $\mathrm{FiO}_{2}$, Fraction on inspired oxygen; PEEP, Positive End Expiratory Pressure; rpm, rounds per minute; Ppeak, Peak Pressure; SOFA, Sequential Organ Failure Assessment Score; GCS, Glasgow Coma Score; CRP, C Reactive Protein; PCT, Procalcitonin

28-day-, in hospital- and 6-month mortality rates were $44 \%$ (8/18), 50\% (9/18) and 50\%, respectively. In-hospital mortality was $29 \%(2 / 7)$ in solid organ transplantation patients and $50 \%(3 / 6)$ in hemopoietic stem cell transplantation patients. In-hospital mortality was $73 \%$ in patients who required secondary intubation and $14 \%$ in patients who did not require intubation while on ECMO support ( $\mathrm{p}=0.023$, Hazard Ratio: $0.133(0.058-0.789))$. 
Table 2 Predictors for failure of the awake ECMO concept

\begin{tabular}{|c|c|c|c|c|c|c|}
\hline \multirow[t]{2}{*}{ Characteristic } & \multicolumn{3}{|c|}{ Secondary intubation } & \multicolumn{3}{|c|}{ Logistic regression } \\
\hline & No & Yes & $p$ & OR & $95 \%-\mathrm{Cl}$ & $p$ \\
\hline Benzodiazepine use during ECMO support—no (\%) & 2/7 (28.6) & $8 / 11(72.7)$ & 0.066 & 6.7 & $0.8-55$ & 0.078 \\
\hline Ppeak (NIV) before ECMO initiation- $\mathrm{cmH} 2 \mathrm{O}$ & $15(11-16)$ & $19(17-22)$ & 0.014 & 1.6 & $1-2.6$ & 0.05 \\
\hline pCO2 before ECMO initiation- $\mathrm{mmHg}$ & $37(35-43)$ & $50(34-76)$ & 0.06 & 1.1 & $1-1.2$ & 0.163 \\
\hline ECMO support duration—days & $9(8-11)$ & $12(10-28)$ & 0.049 & 1.2 & $0.9-1.5$ & 0.173 \\
\hline
\end{tabular}

Description of parameters that were associated with the necessity of later secondary intubation. Factors associated with later failure of an awake ECMO concept were more prominent use of benzodiazepines during awake ECMO support, higher peak pressures applied in noninvasive ventilation and hypercapnia directly before ECMO insertion as well as longer ECMO support. Values are presented as median (25-75\% interquartile range) or if categorical as numbers and percentage

$\mathrm{Cl}$, Confidence Interval; NIV, Noninvasive Ventilation; Ppeak, Peak Pressure

An exploratory analysis suggested several factor associated with later failure of an awake ECMO concept (Table 2).

Although this study, to the best of our knowledge, represents the largest experience with awake ECMO in ARDS patients, conclusions are still limited by its small sample size and the uncontrolled nature. Despite these limitations, our findings support the notion that an awake ECMO strategy might be a viable treatment option for immunocompromised patients with severe ARDS, especially in those patients without overt multi-organ failure. Further studies are required to determine the possible role of the awake ECMO concept in patients with ARDS.

\section{Acknowledgements}

Not applicable.

\section{Authors' contributions}

KS and HS obtained clinical data. KS, HS, CK, OW, MMH and SD analyzed and discussed the data and generated figures and tables. SD, MMH, HS and KS wrote the manuscript; all authors proof-read the manuscript.

\section{Funding}

Open Access funding enabled and organized by Projekt DEAL. SD is supported by the German Research Foundation (DA 1209/4-3) and by the German Lung Centre (DZL). CK and MMH were supported by the German Research Foundation (DFG), Clinical Trails Research Group (KFO 311) "(Pre)terminal heart and lung failure: Unloading and repair".

\section{Availability of data and materials}

The datasets used and/or analyzed during the current study are available from the corresponding author on reasonable request.

\section{Declarations}

\section{Ethics approval and consent to participate}

Ethical approval was waived due to the retrospective nature of this study. The study was performed in accordance with the ethical standards laid down in the 1964 Declaration of Helsinki and its later amendments.

\section{Competing interests}

The authors declare that they have no competing interests.

\section{Author details}

${ }^{1}$ Department of Gastroenterology, Hepatology and Endocrinology, Hannover Medical School, Hannover, Germany. ${ }^{2}$ Department of Nephrology and Hypertension, Hannover Medical School, Hannover, Germany. ${ }^{3}$ Department of Cardiothoracic, Transplant and Vascular Surgery, Hannover Medical School, Hannover, Germany. ${ }^{4}$ Department of Respiratory Medicine and German Centre of Lung Research (DZL), Hannover Medical School, Hannover, Germany. ${ }^{5}$ Institute of Intensive Care Medicine, University Hospital Zurich, Zürich, Switzerland.

Received: 4 February 2021 Accepted: 26 April 2021

Published online: 30 April 2021

\section{References}

1. Combes A, Peek GJ, Hajage D, Hardy P, Abrams D, Schmidt M, et al. ECMO for severe ARDS: systematic review and individual patient data metaanalysis. Intensive Care Med. 2020;46(11):2048-57.

2. Chiu LC, Lin SW, Chuang LP, Li HH, Liu PH, Tsai FC, et al. Mechanical power during extracorporeal membrane oxygenation and hospital mortality in patients with acute respiratory distress syndrome. Crit Care. 2021;25(1):13.

3. Langer T, Santini A, Bottino N, Crotti S, Batchinsky Al, Pesenti A, et al. "Awake" extracorporeal membrane oxygenation (ECMO): pathophysiology, technical considerations, and clinical pioneering. Crit Care. 2016;20(1):150.

4. Hoeper MM, Wiesner O, Hadem J, Wahl O, Suhling H, Duesberg C, et al. Extracorporeal membrane oxygenation instead of invasive mechanical ventilation in patients with acute respiratory distress syndrome. Intensive Care Med. 2013;39(11):2056-7.

5. Schmidt M, Schellongowski P, Patroniti N, Taccone FS, Reis Miranda D, Reuter J, et al. Six-month outcome of immunocompromised severe ARDS patients rescued by ECMO. An international multicenter retrospective study. Am J Respirat Crit Care Med. 2018;

6. Stahl K, Seeliger B, Hoeper MM, David S. "Better be awake"-a role for awake extracorporeal membrane oxygenation in acute respiratory distress syndrome due to Pneumocystis pneumonia. Crit Care. 2019;23(1):418.

\section{Publisher's Note}

Springer Nature remains neutral with regard to jurisdictional claims in published maps and institutional affiliations.

\section{Consent for publication}

Not applicable. 